\title{
The role of frames, numbers and risk in the frequency of cooperation
}

\author{
by \\ Antoni Bosch-Domènech \\ Universitat Pompeu Fabra \\ and Barcelona GSE \\ antoni.bosch@upf.edu \\ and \\ Joaquim Silvestre \\ University of California, Davis \\ jbsilvestre@ucdavis.edu
}

\begin{abstract}
We report on a simple experiment that addresses three factors in the frequency of cooperation: (i) framing, (ii) the number of players and (iii) the perceived risk of cooperating. We work with a (two-player) Prisoner's Dilemma and with a three-player, two-strategy Public Good Game.

These themes have been separately studied by a large number of experimental papers, using diverse methodologies. Our experiment targets them in a common, clear-cut framework. We find three strong effects (a) Framing; (b) The number of players (there is less cooperation in the three-person games that in the two-person ones); (c) The neutralization of risk (about $50 \%$ of participants cooperate when risk is neutralized). Both (a) and (c) go in the expected direction but, in all three cases, the strength of the effect is surprising.
\end{abstract}

Key Words: Cooperation, Framing, Prisoner's Dilemma, Risk, Public Good Game, Voluntary Contribution Game.

JEL Classification Numbers: C74, C91, D74, H41 


\title{
The role of frames, numbers and risk in the frequency of cooperation
}

\author{
Antoni Bosch-Domènech and Joaquim Silvestre*
}

December 30, 2015

\section{Introduction}

An enormous experimental literature addresses cooperation in the Prisoner's Dilemma and in other symmetric games, with various numbers of players, where, in terms of the experimental payoffs, not cooperating is a dominant strategy, but universal cooperation Pareto dominates universal noncooperation. Here we add to this literature by reporting on a quite simple experiment that addresses the importance in the frequency of cooperation of (i) framing, (ii) the number of players and (iii) the neutralization of risk.

These themes have been experimentally studied in a large number of papers, using diverse methodologies. Our experiment targets them in a common, clear-cut framework. In a nutshell, we find a strong framing effect, a strong, negative numbers effect (there is less cooperation with three participants in the game than with two) and a strong effect of the neutralization of risk.

\section{Experimental design}

We performed five treatments.

* 1-Person Risky Decision (Istanbul)

* 3-Person, Frameless Public Good (Frameless PG)

* 3-Person, Framed Public Good (Framed PG)

* 2-Person, Frameless Prisoner's Dilemma (Frameless PD)

* 2-Person, Riskless \& Frameless Prisoner's Dilemma (Riskless \& Frameless PD).

\footnotetext{
*Bosch-Domènech: Universitat Pompeu Fabra, Barcelona and Barcelona Graduate School of Economics $<$ antoni.bosch@upf.edu>. Silvestre: University of California, Davis <jbsilvestre@ucdavis.edu>. John Roemer's $(2015 \mathrm{a}, \mathrm{b})$ work on Kantian optimization has motivated our wish to contribute to the understanding of why people do cooperate when they do. Some of the results in this paper were presented at the conference "Social Welfare, Justice and Distribution: Celebrating John Roemer's contributions to economics, political philosophy and political science," Queen Mary University of London, June 19-20, 2015. We gratefully acknowledge the assistance of Pablo LópezAguilar Beltrán, Manager of the BES_Lab, and financial support from Ministerio de Economía y Competitividad, grant ECO2014-56154-P. We are indebted to John Roemer for useful discussions, to Drew Fudenberg, Ted Bergstrom and Juan Camilo Cárdenas for comments, and to Jordi Silvestre-Ryan for suggestions. The usual caveat applies with full force.
} 
All treatments were one-shot (no repetitions). Participants in the experiment played in only one treatment (between-subjects experiment). In each of the five treatments, they had to make a single decision between two alternatives. Except for the Framed PG treatment, where participants had to choose between To CONTRIBUTE and Not TO CONTRIBUTE, the two alternatives were named Circle and SQuare.

After entering their decision, participants were asked to give a brief explanation of their decision ("open-format explanation"). In all treatments except the Istanbul treatment, after providing the open-format explanation, participants had to choose among several alternatives for the "most influential reason in your decision" (“closed-format explanation"). ${ }^{1}$

In all treatments:

(i) The individual payoff of a player always increased by $€ 5$ if he/she switched from choosing Circle/ To CONTRIBUTE to SQUARE/ NOT TO CONTRIBUTE.

(ii) The sum of payoffs was maximized if everybody chose CIRCLE/ TO CONTRIBUTE, in which case everybody received $€ 10$. At the other extreme, if everybody chose SQUARE/ NOT TO CONTRIBUTE, then the individual payoffs were $€ 6$. Hence, in all our treatments universal cooperation increased individual payoffs by $€ 4$ relative to universal defection.

\subsection{Istanbul Treatment}

The Istanbul Treatment was a control designed to check the strength of the dominant strategy factor in a nonsocial situation. Table 2.1 displays the payoff matrix.

\begin{tabular}{|l|l|l|l|}
\cline { 2 - 4 } \multicolumn{1}{c|}{} & $\begin{array}{l}\text { Temperature in Istanbul } \\
<12^{\circ} \mathrm{C}\end{array}$ & $\begin{array}{l}\text { Temperature in Istanbul } \\
\geq 12^{0} \mathrm{C} \text { but } \leq 15^{\circ} \mathrm{C}\end{array}$ & $\begin{array}{l}\text { Temperature in } \\
\text { Istanbul }>15^{\circ} \mathrm{C}\end{array}$ \\
\hline You choose CIRCLE & You earn $€ 10$ & You earn $€ 5.5$ & You earn $€ 1$ \\
\hline You choose SQUARE & You earn $€ 15$ & You earn $€ 10.5$ & You earn $€ 6$ \\
\hline
\end{tabular}

Table 2.1. Payoff matrix in the Istanbul Treatment

\subsection{3-Person Frameless Public Good Treatment}

In the 3-Person Frameless PG Treatment, each participant faced the payoff matrix of the Istanbul treatment, but, instead of the temperature in Istanbul, the columns corresponded to the number of

\footnotetext{
${ }^{1}$ See the Appendix for the complete description of all treatments.
} 
other participants in his/her 3-person group (randomly and anonymously constituted) who chose CIRCLE. Accordingly, the payoff matrix is given by Table 2.2. Here and in the remaining treatments, the participants were informed that the payoffs of the other players were symmetric to theirs and, in fact, they were explicitly given the payoff matrices of the other players. $^{2}$

\begin{tabular}{|l|l|l|l|}
\cline { 2 - 4 } \multicolumn{1}{c|}{} & $\begin{array}{l}\text { The other two members } \\
\text { of your group choose } \\
\text { CIRCLE }\end{array}$ & $\begin{array}{l}\text { One other member of } \\
\text { your group chooses } \\
\text { CIRCLE and another one } \\
\text { SQUARE }\end{array}$ & $\begin{array}{l}\text { The other two } \\
\text { members of your } \\
\text { group choose } \\
\text { SQUARE }\end{array}$ \\
\hline You choose CIRCLE & You earn $€ 10$ & You earn $€ 5.5$ & You earn $€ 1$ \\
\hline You choose SQUARE & You earn $€ 15$ & You earn $€ 10.5$ & You earn $€ 6$ \\
\hline
\end{tabular}

Table 2.2. Payoff matrix in the 3-Person Frameless PG Treatment

\subsection{3-Person Framed Public Good Treatment}

In the 3-Person Framed PG Treatment, each participant faced the payoff matrix of the 3-Person Frameless PG Treatment but, instead of CIRCLE and SQUARE, the choices we described as in the typical Public Good Game narrative of contributing a token in a group account, where it benefits the whole group (To CONTRIBUTE), vs. investing it in a private account (NOT TO CONTRIBUTE). Accordingly, the payoff matrix is given by Table $2.3 .^{3}$

\begin{tabular}{|l|l|l|l|}
\cline { 2 - 4 } \multicolumn{1}{c|}{} & $\begin{array}{l}\text { The other two } \\
\text { members of your } \\
\text { group choose } \\
\text { TO CONTRIBUTE }\end{array}$ & $\begin{array}{l}\text { One other member of } \\
\text { your group chooses } \\
\text { TO CONTRIBUTE, and } \\
\text { another one NoT TO } \\
\text { CONTRIBUTE }\end{array}$ & $\begin{array}{l}\text { The other two members } \\
\text { of your group choose } \\
\text { NOT TO CONTRIBUTE }\end{array}$ \\
\hline You choose TO CONTRIBUTE & You earn $€ 10$ & You earn $€ 5.5$ & You earn $€ 1$ \\
\hline You choose NOT TO CONTRIBUTE & You earn $€ 15$ & You earn $€ 10.5$ & You earn $€ 6$ \\
\hline
\end{tabular}

Table 2.3. Payoff matrix in the 3-Person Framed PG Treatment

\footnotetext{
2 Strictly speaking, rather that eliminating frames, our "frameless" treatments substitute the abstract framing of CiRCLE/SQUARE for the usual, more descriptive frames of contribution and cooperation.

${ }^{3}$ In the traditional public good game, each player is endowed with a number of tokens (10, say), and she can decide how many to contribute to the group account, and how many to invest in her private account. Here she has only one token, so that she only has two alternatives, as in the Prisoner's Dilemma. In fact, this type of game has often been called " $N$-person Prisoner's Dilemma" in the literature.
} 


\subsection{2-Person Frameless Prisoner's Dilemma Treatment}

In the 2-Person Frameless Prisoner's Dilemma Treatment the payoff matrix is given by Table 2.4.

\begin{tabular}{|l|l|l|}
\cline { 2 - 3 } \multicolumn{1}{c|}{} & $\begin{array}{l}\text { The other player } \\
\text { chooses CIRCLE }\end{array}$ & $\begin{array}{l}\text { The other player } \\
\text { chooses SQUARE }\end{array}$ \\
\hline You choose CIRCLE & You earn $€ 10$ & You earn $€ 1$ \\
\hline You choose SQUARE & You earn $€ 15$ & You earn $€ 6$ \\
\hline
\end{tabular}

Table 2.4. Payoff matrix in the 2-Person Frameless Prisoner's Dilemma Treatment

\subsection{2-Person Riskless and Frameless Prisoner's Dilemma Treatment}

We performed this treatment at a later date spurred by the comments of the participants in the previous treatments. In the standard Prisoner's Dilemma and Public Good experiments, the participants make their moves simultaneously and, hence, they make their decision under uncertainty about the other player's decisions. In fact, we found in the explanations by the participants in our treatments 3-Person Frameless PG, 3-Person Framed PG and 2-Person Frameless PD that aversion to that risk is a major drive of the non-cooperative choice (see Section 5.2 below.)

To remove the risk due to the unknown decision of the other player/s, one can introduce sequential playing so that uncertainty is removed for the player who plays last (see, e. g., Kenneth Clark and Martin Sefton, 2001) or implement a "strategy method" approach (as Urs Fischbacher et al., 2001). We adopted a different procedure. The starting point was the 2-Person Frameless Prisoner's Dilemma game (Table 2.4 above). As before, the participants were randomly matched in pairs. But now they were told in addition that the computer would randomly choose (50\% probability) one of them as active, and the other one as passive: the passive participant had to play CIRCLE necessarily. This removed the risk for the active players.

Compared to the Sequential Playing or Strategy Method designs, our approach neutralizes risk while eliminating in practice the reciprocity motive for cooperating. This simplifies the interpretation of the motivations behind the participants' decisions. As an added bonus, our method guarantees a substantial number of independent observations. In fact, by reversing the roles in a second part of the treatment, we reached a total of 88 decision makers, who made a single decision each. 
Note that the resulting game has features similar to the Random Dictator game. The main difference lies in the options open to the "dictator:" in the canonical Random Dictator game, she can distribute in any way a fixed initial endowment, whereas here the "dictator" (i. e, the active player) chooses between allocating 10 and 10 euros, or 15 and 1 euros.

The payoff table of the active player thus simplifies to Table 2.5.

\begin{tabular}{|l|c|}
\cline { 2 - 2 } \multicolumn{1}{c|}{} & $\begin{array}{c}\text { The other player chooses } \\
\text { CIRCLE }\end{array}$ \\
\hline You choose CIRCLE & You earn $€ 10$ \\
\hline You choose SQUARE & You earn $€ 15$ \\
\hline
\end{tabular}

Table 2.5. Payoffs of the active player in the 2-Person Riskless \& Frameless PG Treatment

After the active players had made their choices and expressed their reasons, and without informing of the active player's decisions, all participants were told that the experiment would continue with the active players turned into passive ones, and vice-versa. They were explicitly told that the active and passive players would be randomly matched again.

In this treatment, we went to some lengths to guarantee the anonymity of the decisions. Of course, in all treatments players were never aware of the decision of any other identifiable player. But in the previous treatments the experimenters knew the earnings (and indirectly the decision) of each participant, since participants had to sign a receipt with their name and the amount earned. Here, after getting a green light from the university Research Office, we implemented the following procedure.

(i) Before starting the experiment, each participant signed a document with his/her name acknowledging his/her participation in a paid experiment but, obviously, without stating any specific amount of money earned

(ii) At the end of the experiment, the next-to-last screen in each individual terminal displayed the total amount earned by the participant (as an active and as a passive player). After the participant clicked "Continue," the last screen simply showed a letter code (two possible letters for each of the possible amounts of earnings). A university beadle unrelated to the experiment walked past each participant handing a closed envelope 
(containing the appropriate earnings) marked with the letter that matched the one in the screen.

(iii) To justify the total expenditure of research funds, the experimenters submitted an affidavit stating the total amount included in the envelopes distributed, together with the documents signed by the participants.

\section{The experiment}

The participants were undergraduate students at Universitat Poтреи Fabra. We avoided economics and business majors, who may be too familiar with PD and PG games, so that most of them majored in law, political science or the humanities. We attempted, with approximate success, an equal number of men and women. The experiment took place at the BES_Lab of Universitat Pompeu Fabra.

The Istanbul Treatment was quite simple. Participants were individually taken to a separate room, where the instruction sheet was given. After they had made their choice, they were asked to provide the open-format explanation. Once completed, the temperature in Istanbul was checked and the participants paid accordingly. The Istanbul Treatment involved only seven participants.

Each of three treatments Frameless PG, Framed PG and Frameless PD was conducted in two sessions, involving from 21 to 24 participants, for a total of $N=47$ in Frameless PG, $N=42$ in Framed PG, and $N=46$ in Frameless PD. Once they were all seated, the screen with instructions appeared, and the instructions were also read aloud. After all participants made their choices and clicked "continue," a second screen appeared asking for the open-format explanation and, after all participants clicked "continue," a third screen asked to choose the closed-format explanation. Next, each participant was informed of his/her earnings, was paid and left. The whole session lasted about half an hour.

The Riskless \& Frameless PD was conducted in four sessions, with a total of $N=88$ participants. See Section 2.5 above for a description. Each session lasted slightly more than half an hour.

\section{Results}

Table 1 presents the experimental results.

The control "Istanbul" treatment yielded the predictable outcome of no CIRCLE choices. 
Result 1. Framing the choices in the 3-Person Public Good treatment increases cooperation.

The 3-Person Frameless PG resulted in a very low level of cooperation: only $2 \%$ of the participants chose CIRCLE. ${ }^{4}$ This contrasts with the cooperation obtained in the 3-Person Framed PG Treatment (21\%). Because in the existing experimental literature public goods are often framed by a narrative of contributing to a common account, our experiment shows that this framing is fundamental. ${ }^{5}$ An abstract presentation of the same game yields very low levels of cooperation. ${ }^{6}$

All the treatments mentioned in the following results are of the frameless variety.

Result 2. Reducing the number of players increases cooperation.

Our second result is that it matters whether it is a 2-person vs. 3-person game. We see more cooperation (28\%) in the 2-Person Frameless Prisoner's Dilemma than in the 3-Person Frameless Public Good Game (2\%).

Our results also suggest more cooperation in the 2-Person Frameless Prisoner's Dilemma (28\%) than in the 3-Person Framed PG Treatment (21\%). Despite the pro-cooperation effect of the frame, going from an abstract 2-person game to a framed 3-person one decreases cooperation.

The literature on the effects of numbers on cooperation does not give unanimous results: it depends on the strategic situations. The Prisoner's Dilemma generated an early stream of experimental work starting in the 1950's. Andrew Colman (1995) provides a useful review of it, as well as of the 1970's studies in the effects of group size. This early experimental literature was typically carried out by social psychologists and sociologists. These often, but not always, ${ }^{7}$ showed that the frequency of cooperation would decrease as the number of players increases, as we have found in our experiment. As presented in the review by John Ledyard (1995), economists started in

\footnotetext{
${ }^{4}$ We do not include one participant who chose CIRCLE but stated, both in the open question and in the closed question, that she made her choice at random. No other participant said that.

5 This confirms results found in the literature, see e. g., R. Cookson (2000).

${ }^{6}$ We have not attempted to address the frame-no frame issue for the Prisoner's Dilemma, since the experimental literature already frequently uses abstracts descriptions of the choices (such as UP-DOWN, LEFT-RIGHT).

${ }^{7}$ See, for instance, Phillip Bonacich et al. (1976)
} 
the 1980's to do experimental work on free riding. The effects of the number of participants were studied by Marc Isaac, James Walker and Arlington Williams (1994), who found that increasing the number of players sometimes increased the frequency of cooperation. Ledyard's "stylized fact" (p. 143) is that the number of players has no effect on the frequency of cooperation. More recent work also shows both positive and negative group-size effects (see, e. g., Joachim Weimann et al., 2012, Hélène Barcelo and Valerio Capraro, 2015).

However, we do find a strong effect in the direction of "higher numbers, less cooperation."8 It is not clear from the answers of participants whether this is mostly due to an increase in the risk of facing non-cooperators as the numbers increase (see Section 5.2 below), or to the added complexity of the game leading them to take the easier path.

\begin{tabular}{|c|c|c|c|c|c|}
\hline & Istanbul & Frameless PG & Framed PG & Frameless PD & $\begin{array}{l}\text { Riskless \& } \\
\text { Frameless PD }\end{array}$ \\
\hline $\begin{array}{l}\text { CIRCLE } \\
\text { (CONTRIBUTE in the } \\
\text { Framed PG) }\end{array}$ & $\begin{array}{l}0 / 7 \\
\mathbf{0 \%}\end{array}$ & $\begin{array}{l}1 / 47 \\
\mathbf{2 \%}\end{array}$ & $\begin{array}{l}9 / 42 \\
\mathbf{2 1 \%}\end{array}$ & $\begin{array}{l}13 / 46 \\
\mathbf{2 8 \%}\end{array}$ & $\begin{array}{l}43 / 88 \\
49 \%\end{array}$ \\
\hline $\begin{array}{l}\text { SQUARE (DO NOT } \\
\text { CONTRIBUTE in the } \\
\text { Framed PG) }\end{array}$ & $\begin{array}{l}7 / 7 \\
100 \%\end{array}$ & $\begin{array}{l}46 / 47 \\
98 \%\end{array}$ & $\begin{array}{l}33 / 42 \\
79 \%\end{array}$ & $\begin{array}{l}33 / 46 \\
72 \%\end{array}$ & $\begin{array}{l}45 / 88 \\
\mathbf{5 1 \%}\end{array}$ \\
\hline
\end{tabular}

Table 4.1. Experimental Results.

Result 3. Neutralizing risk increases cooperation.

Neutralizing risk in the Frameless Prisoner's Dilemma increases cooperation from $28 \%$ to a notable $49 \%$. As indicated above, and contrary to all other treatments, in the Riskless and Frameless PD decisions were anonymous also vis-à-vis the experimenters. Conceivably, anonymity by itself could reduce cooperation by diminishing possible experimenter effects, which makes the anonymous cooperation level of $49 \%$ even more remarkable for a one-shot Prisoner's Dilemma experiment.

\footnotetext{
8 Daniele Nosenzo et al. (2015) also find more cooperation when the number of players is two rather than three, four or eight, in a different strategic setup (repeated 10-period Public Good game with variable levels of contribution).
} 


\section{Participants' comments}

While difficult to quantify, the participants' explanation of their decisions, in both its open and closed formats, provides insights about their understanding of the issue and about their motivation.

\subsection{Awareness of strategic dominance}

Recall that in all treatments the "SQUARE," or "Do NOT CONTRIBUTE," option is a dominant strategy for the game with the experimental payoffs. ${ }^{9}$ In the Istanbul Treatment, not only all participants choose "SQUARE," but, interestingly, all but one clearly and explicitly gave, in the open format explanation, the dominant-strategy argument ("by choosing SQUARE I get more money no matter what the temperature is in Istanbul"). ${ }^{10}$ Similarly, in the 2-Person Riskless \& Frameless PD Treatment, those who chose SQUARE clearly reasoned in terms of maximizing gains.

This stands in strong contrast with the Frameless PG, Framed PG and Frameless PD treatments. In them, only $22 \%$ of the participants who chose SQUARE/DO NOT CONTRIBUTE did show a clear understanding of the dominant-strategy argument in the open format explanation. Yet, their answers in the closed-ended format favored the dominant-strategy idea by a larger margin, namely $39 \%$, whereas a $36 \%$ chose options referring to the risk induced by the unknown decisions of the other player/s in the group. The remaining $25 \%$ chose the option that referred to the equilibrium of the Prisoner's Dilemma game.

\subsection{Decision under risk}

Among the remaining 78\% of participants who chose SQUARE/Do NOT CONTRIBUTE in the Frameless PG, Framed PG and Frameless PD treatments, the most frequent explanations in the open format centered in risk taking ("choosing CIRCLE is too risky") and/or in maximizing the lowest payoff (€6 with SQUARE vs. €1 with CIRCLE).

But if you understand the dominant-strategy argument, and if you only care about the money payoff, then SQUARE first-order stochastically dominates CIRCLE, and risk considerations should be irrelevant.

\footnotetext{
9 Of course, in the 2-Person Riskless \& Frameless PD Treatment, SQUARE is trivially a "Dominant Strategy" since the other player has a single option.

${ }^{10}$ As indicated above, only the open format was used with the participants in the Istanbul Treatment. The remaining participant just said that the SQUARE choice was "safer and more convenient."
} 
So why did so many among the participants who chose SQUARE/DO NOT CONTRIBUTE refer to risk? Granted, we should not underestimate the role of a lack of understanding of the Dominant Strategy property: this did not appear to be a problem in the Istanbul Treatment, but the information in the other treatments also included the payoffs of the other player or players, and even though the payoff tables were isomorphic, the additional information could conceivably have obscured the dominant-strategy property of SQUARE/DO NOT CONTRIBUTE.

Nevertheless, the wording of the explanations suggests that many of the participants who chose SQUARE/DO NOT CONTRIBUTE did initially find some attractiveness in the CIRCLE/CONTRIBUTE option, but realized that it had a serious downside if the other participant/s did not contribute, and decided not to take the risk. This suggests that some of the people who do not cooperate because they find cooperation too risky might, in fact, cooperate if they were assured that the other player or players do cooperate. This motivated our 2-Person Riskless \& Frameless PD Treatment.

\subsection{Decisions under certainty}

As noted above, $51 \%$ of the participants in the 2-Person Riskless \& Frameless PD Treatment chose SQUARE. In their explanations in the open format, except for the very few who evidenced a lack of understanding of the instructions, they all clearly stated that they chose SQUARE in order to maximize gains. Several tried to justify their decision not to cooperate (SQUARE) by referring to the fact that they were playing with a stranger. Others, among those who were active in the second part of the experiment, tried to justify their decision by envisioning that the corresponding active player in the first part had "obviously" inflicted SQUARE on them: they would then play SQUARE when active to compensate for the imagined low earnings in the first part.

Next, in the closed-format explanation of their decision, those who chose SQUARE faced the following list of reasons to choose from:

* I chose at random

* It is the most profitable option for me

* This game is similar to the Prisoner's Dilemma, in which case theory tells us to make this decision.

By a large margin (84\%), they chose the second option, whereas the remaining $16 \%$ chose the last one. 
We were particularly interested in eliciting the reasons of those who chose CIRCLE. We focused our attention in the following possible motivations: ${ }^{11}$

\section{Efficiency}

\section{Equity / Fairness}

\section{Altruism}

We were also curious about the role of, in Roemer's (2015a, b) terms, the Kantian optimization protocol, i. e., the selection of the common strategy that would maximize the expected gains of a player facing a 50-50 chance of being active or passive.

To that end, the closed-format list had five options:

* I chose at random

* It is the choice that I'd like everybody to make in this situation

* I like to help others even at a cost to myself

* In this manner, our joint earnings are higher

* Taking advantage of others is not right.

The modal response (49\%) was the fourth one, which indicates a concern for efficiency. The second most frequent was the second one (37\%), which suggests Kantian-type thinking. Next came the last one (9\%), which suggests fairness. Only 4\% chose the third option, which is related to altruism. ${ }^{12}$ (Nobody chose the first option.)

But the explanations in the open format (answered before they faced the closed-format list) provide a somewhat different picture. We disregard answers too confuse to be characterized (19\%), and compute the frequencies among the $81 \%$ remaining ones. A large fraction of those (46\%), which include many of those who chose the "Kantian" answer in the closed format, provided reasons related to fairness and equity. Next, 31\% (including many of those who, consistently, choose the fourth option in the closed format) reasoned in terms of efficiency. The remaining $23 \%$ offered answers that combined elements of altruism, equity, efficiency and Kantian thinking.

\footnotetext{
11 Reciprocity, as a drive for cooperation (see, e. g., Samuel Bowles and Herbert Gintis, 2011), does not have a natural fit in our experimental design because either the moves are simultaneous or one player does not choose freely (2-Person Riskless \& Frameless PD: see Section 2.5 above).

12 Clark and Sefton (2001) also rule out altruism as the frequent motivation for cooperation, finding that reciprocity is the main factor. Our experiments suggest that, even in the absence of a role for reciprocity, altruism remains a minor motivation, whereas considerations of efficiency, and to a lesser extent fairness, dominate.
} 


\section{Conclusion}

We have studied three factors affecting cooperation in 2-person Prisoner's Dilemmas and 3-person Public Good experiments:

1. Frames

2. Number of players

3. Risk.

We find that all three factors have a strong influence. As detailed in Section 4, cooperation increases:

* When moving from frameless 3-player (2\%) to framed 3-player (21\%) treatments.

* When moving from frameless 3-player (2\%) to frameless 2-player (28\%) treatments.

* When moving from frameless 2-player (28\%) to riskless \& frameless 2-player (49\%) treatments. The latter treatment was performed under anonymity, so that the experimenters could not observe or infer individual decisions.

In the (nonsocial) Istanbul treatment participants followed and clearly expressed the dominant-strategy logic. Also, in the single-agent decision of the Riskless \& Frameless PD treatment, noncooperators (a 51\% of participants) clearly stated the earning maximization motive. But in the social, multi-agent treatments (3-Person Frameless PG, 3-Person Framed PG, 2-Person Frameless PD), the motivations appear to be more confused and, interestingly, imbued by considerations of risk.

The stated motivations of the participants who chose to cooperate (TO CONTRIBUTE in the Framed PG, CiRCLE in the 3-Person Frameless PG, 2-Person Frameless PD, 2-Person Riskless \& Frameless PD) centered in efficiency and fairness, in that order, with little mention of altruism.

The scant role of altruism and the fact that efficiency played a larger role than fairness are surprising to some extent. It should be noted that the efficiency explanations were cast in terms of maximizing communal earnings rather than of avoiding waste.

The Kantian reasoning appears mostly in the form: "I, active, do what I'd like the other person to do were I passive," and usually combined with the notions of efficiency and fairness, which is not surprising in our simple, symmetric games. 


\section{APPENDIX}

\section{A.1. Istanbul Treatment}

Participants were given a paper page with the following text. After they chose, they were orally asked to write, at the bottom, a short explanation of the reasons for their decision.

\section{INSTRUCCIONES}

Puedes escoger o bien CírCulo o bien CuAdRAdo, pero no ambos. Tus ganancias dependerán de tu decisión y también de la temperatura en Estambul al final del experimento (según $C N N$ Weather). Más exactamente, tus ganancias vienen descritas en el cuadro siguiente.

\begin{tabular}{|l|l|l|l|}
\cline { 2 - 4 } \multicolumn{1}{c|}{} & $\begin{array}{l}\text { Temperatura en } \\
\text { Estambul }<12^{0} \mathrm{C}\end{array}$ & $\begin{array}{l}\text { Temperatura en } \\
\text { Estambul } \geq 12^{0} \mathrm{C} \\
\text { pero } \leq 15^{0} \mathrm{C}\end{array}$ & $\begin{array}{l}\text { Temperatura en } \\
\text { Estambul }>15^{\circ} \mathrm{C}\end{array}$ \\
\hline Tú escoges CíRCULO & Tú ganas $10 €$ & Tú ganas 5.5 & Tú ganas 1 \\
\hline Tú escoges CUADRADO & Tú ganas 15 & Tú ganas 10.5 & Tú ganas 6 \\
\hline
\end{tabular}

Tus ganancias

\section{Tú escoges}

CírCulo

\section{CUADRADO}

(Marca con una cruz lo que hayas escogido) 


\section{A.2. 3-Person Frameless Public Good (PG) Treatment}

Frameless PG. Screen 1: Instructions and choice

Vas a jugar junto con otros dos jugadores que han sido escogidos al azar entre los participantes en este experimento, de manera que formáis un grupo de tres personas. Tú puedes escoger o bien CIRRCULO o bien CUADRADO, pero no ambos. Cada uno de los otros jugadores de tu grupo dependen de tu decisión y de la decisión que cada uno de ellos tome; las ganancias de cada uno de los tres

jugadores del grupo pueden muy bien ser distintas pero se calculan siguiendo las mismas reglas. Más exactamente, tus ganancias y las de los otros dos jugadores de tu grupo vienen descritas en los cuadros siguientes donde, como puedes comprobar, las ganancias de los tres jugadores del grupo se calculan de la misma manera.

Tu cuadro de ganancias

\begin{tabular}{|c|c|c|c|}
\hline & Los otros dos jugadores escogen CíRCULO & $\begin{array}{l}\text { Uno de los otros dos escoge círCULO y el } \\
\text { totra CUDRRADO }\end{array}$ & Los otros dos jugadores escogen CUADRADO \\
\hline Tú escoges círCulo & Tú ganas $10 €$ & Tú ganas $5.5 €$ & Tú ganas $1 €$ \\
\hline Tú escoges CUADRADO & Tú ganas $15 €$ & Tú ganas $10.5 €$ & Tú ganas $6 €$ \\
\hline
\end{tabular}

Cuadro de ganancias de uno cualquiera de los otros dos jugadores (llamémosle jugador 2)

\begin{tabular}{|c|c|c|c|c|}
\hline & Tanto tú como o lj jugador restante escogéis CirRCULO & $\begin{array}{l}\text { Tú escoges cirCULO y el jugador restante escoge } \\
\text { CUAPRADO }\end{array}$ & $\begin{array}{l}\text { Tú escoges CUADRAD y el jugador restante } \\
\text { escogoc eifCULO }\end{array}$ & $\begin{array}{l}\text { Tanto tí como el jugador restante escogeis } \\
\text { CUARADO }\end{array}$ \\
\hline El jugador 2 escoge circulo & El jugador 2 gana $10 €$ & El jugador 2 gana $5.5 €$ & El jugador 2 gana $5.5 €$ & El jugador 2 gana $1 €$ \\
\hline Eljugador 2 escoge CUADRADO & El jugador 2 gana $15 €$ & Eljugador 2 gana $10,5 \epsilon$ & El jugador 2 gana $10,5 \in$ & El jugador 2 gana $6 €$ \\
\hline
\end{tabular}


Frameless PG. Screen 2: Open-format explanation

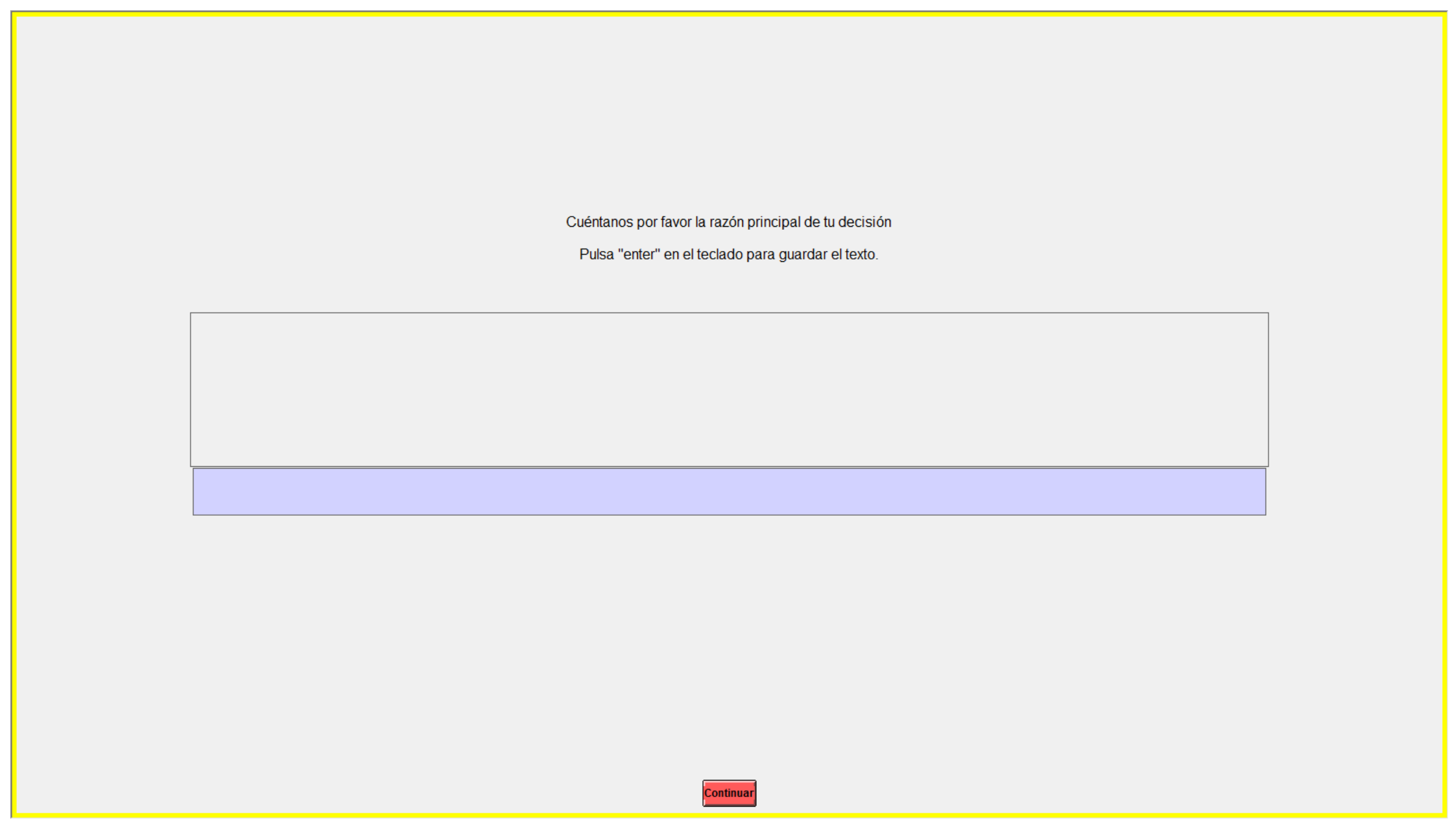


Frameless PG. Screen 3A: Closed-format explanation from a participant who chose CIRCLE

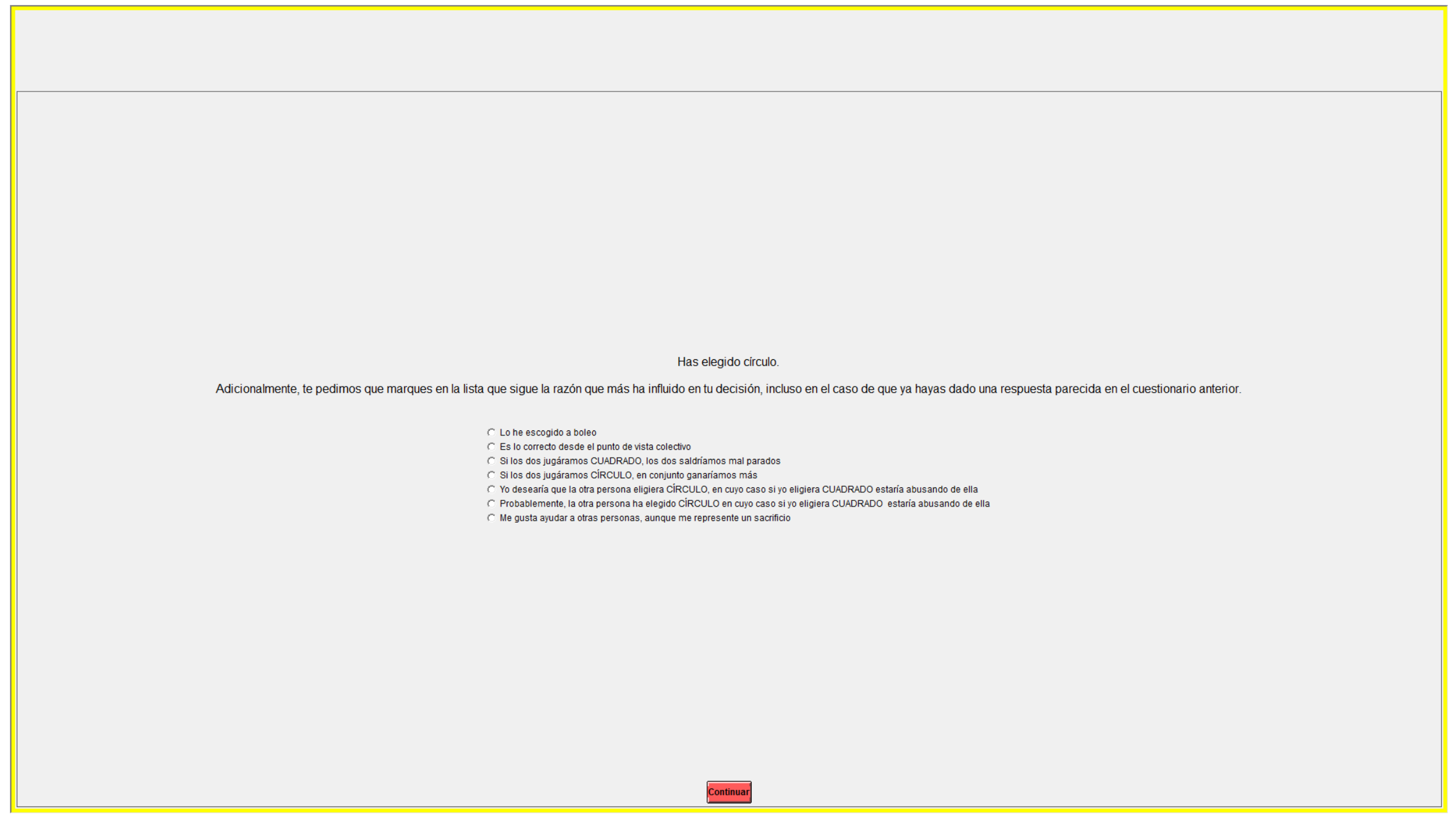


Frameless PG. Screen 3B: Closed-format explanation from a participant who chose SQUARE

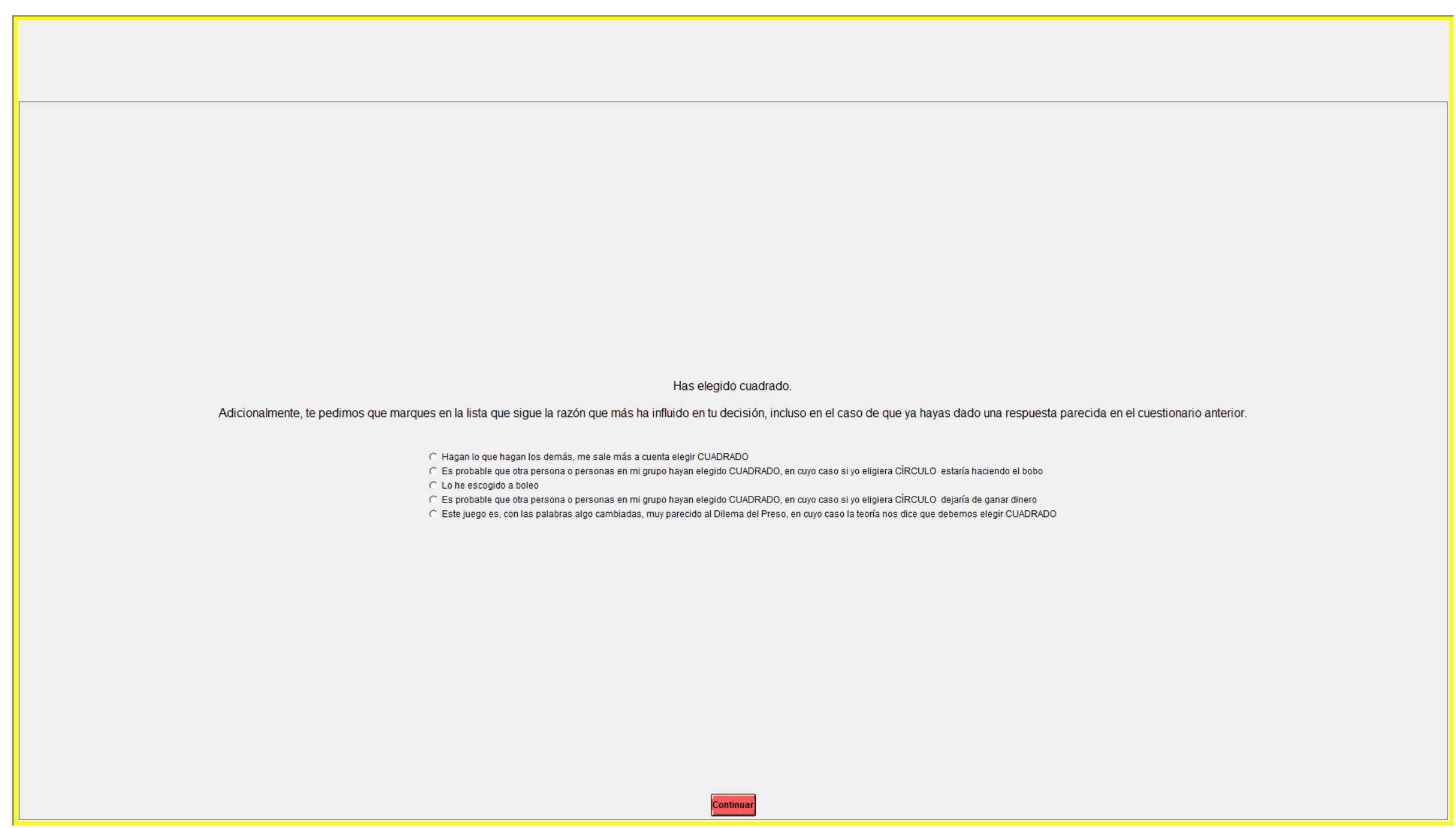


Frameless PG. Screen 4: Earnings statement (example)

Has ganado 1.0 Euros.

continuar 
A.3. 3-Person Framed Public Good (PG) Treatment

Framed PG. Screen 1: Instructions and choice

Vas a jugar con otros dos jugadores que han sido escogidos al azar entre los participantes en este experimento, de manera que formáis un grupo de tres miembros. Cada miembro del grupo dispone de una Cuenta Privada, y el grupo en sí dispone de una cuenta separada llamada la Cuenta del Grupo. Personalmente, tú posees una Ficha y tienes que tomar una sola decisión: o bien aportar tu Ficha a la Cuenta del Grupo, o bien colocar tu Ficha en tu Cuenta Privada.

Cada uno de los otros dos miembros del grupo posee también su propia Ficha y tiene que tomar idéntica decisión. Tanto tus ganancias como las de los otros dos miembros de tu grupo dependen de tu decisión y de la decisión que cada uno de ellos tome; las ganancias de cada uno de los tres miembros pueden muy bien ser distintas, pero se calculan siguiendo las mismas reglas.

Cada Ficha aportada a la Cuenta del Grupo se convierte en 13,5€, a repartir en partes iguales entre los tres miembros del grupo, con independencia de si los demás han aportado 0 no su Ficha a la Cuenta del Grupo. Pero si la colocas en tu Cuenta Privada, tu Ficha se convierte en $9,5 €$. Por otro lado, una tasa fija de $3,5 €$ se deduce, independientemente de cualquier decisión, de las ganancias de cada miembro del grupo.

En consecuencia, si aportas tu Ficha a la Cuenta del Grupo tus ganancias totales son un tercio del total en euros aportados a la Cuenta del Grupo (que incluye tu aportación) menos la tasa de $3.5 €$ Si, por el contrario, colocas tu Ficha en tu Cuenta Privada, entonces tus ganancias son un tercio del total en euros aportados a la Cuenta del Grupo (que ahora no incluye aportación alguna de tu parte), más los $9,5 €$ provenientes de tu Ficha colocada en tu Cuenta Privada, menos la tasa de $3,5 €$

En otras palabras, tus ganancias y las de los dos otros miembros de tu grupo vienen descritas en los cuadros siguientes, donde comprobarás que las ganancias de los tres miembros del grupo se calculan de la misma manera "Contribuye" significa "aporta la Ficha a la Cuenta del Grupo", mientras que "no contribuye" significa "coloca la Ficha en la correspondiente Cuenta Privada".

Tu cuadro de ganancias

\begin{tabular}{|c|c|c|c|}
\hline & Los dos otros miembros de tu grupo contribuyen & Uno de los demás miembros contribuye, y el otro no & Ninguno de los otros miembros de tu grupo contribuye \\
\hline Tú contribuyes & $\begin{array}{c}\text { Tú ganas } \\
(3 \times 13,5 / 3)-3,5= \\
10 €\end{array}$ & $\begin{array}{c}\text { Tú ganas } \\
(2 \times 13,5 / 3)-3,5= \\
5,5 €\end{array}$ & $\begin{array}{c}\text { Tú ganas } \\
\underset{(1 \times 13,5 / 3)-3,5=}{1 €}\end{array}$ \\
\hline Tú no contribuyes & $\begin{array}{c}\text { Tú ganas } \\
(2 \times 13,5 / 3)+9,5-3,5= \\
\mathbf{1 5 , 5 €}\end{array}$ & $\begin{array}{c}\text { Tú ganas } \\
(1 \times 13,5 / 3)+9,5-3,5= \\
\mathbb{1 0 , 5 €}\end{array}$ & $\begin{array}{l}\text { Tú ganas } \\
(0 \times 13,5 / 3)+9,5-3,5= \\
6 €\end{array}$ \\
\hline
\end{tabular}

Cuadro de ganancias de uno cualquiera de los otros dos jugadores (llamémosle jugador 2)

\begin{tabular}{|c|c|c|c|c|}
\hline & $\begin{array}{l}\text { Tanto tú como el miembro restante } \\
\text { contribuís }\end{array}$ & Tú contribuyes, pero el miembro restante no & $\begin{array}{l}\text { Tú no contribuyes, pero el miembro restante } \\
\text { contribuye }\end{array}$ & Ni tú ni el miembro restante contribuis \\
\hline El Miembro 2 contribuye & $\begin{array}{l}\text { El Miembro } 2 \text { gana } \\
(3 \times 13,5 / 3)-3,5= \\
10 €\end{array}$ & $\begin{array}{l}\text { El Miembro } 2 \text { gana } \\
(2 \times 13,5 / 3)-3,5= \\
5,5 €\end{array}$ & $\begin{array}{l}\text { El Miembro } 2 \text { gana } \\
(2 \times 13,5 / 3)-3,5= \\
5,5 €\end{array}$ & $\begin{array}{l}\text { ElMiembro } 2 \text { gana } \\
\qquad \begin{array}{c}(1 \times 13,5 / 3)-3,5= \\
1 €\end{array}\end{array}$ \\
\hline El Miembro 2 no contribuye & $\begin{array}{l}\text { El Miembro } 2 \text { gana } \\
(2 \times 13,5 / 3)+9,5-3,5= \\
\mathbf{1 5 , 5 €}\end{array}$ & $\begin{array}{l}\text { El Miembro } 2 \text { gana } \\
(1 \times 13,5 / 3)+9,5-3,5= \\
\mathbf{1 0 , 5 €}\end{array}$ & $\begin{array}{l}\text { El Miembro } 2 \text { gana } \\
(1 \times 13,5 / 3)+9,5-3,5= \\
\mathbf{1 0 , 5 €}\end{array}$ & $\begin{array}{l}\text { El Miembro } 2 \text { gana } \\
(0 \times 13,5 / 3)+9,5-3,5=\end{array}$ \\
\hline
\end{tabular}

Tú escoges: 
Framed PG. Screen 2: Open-format explanation

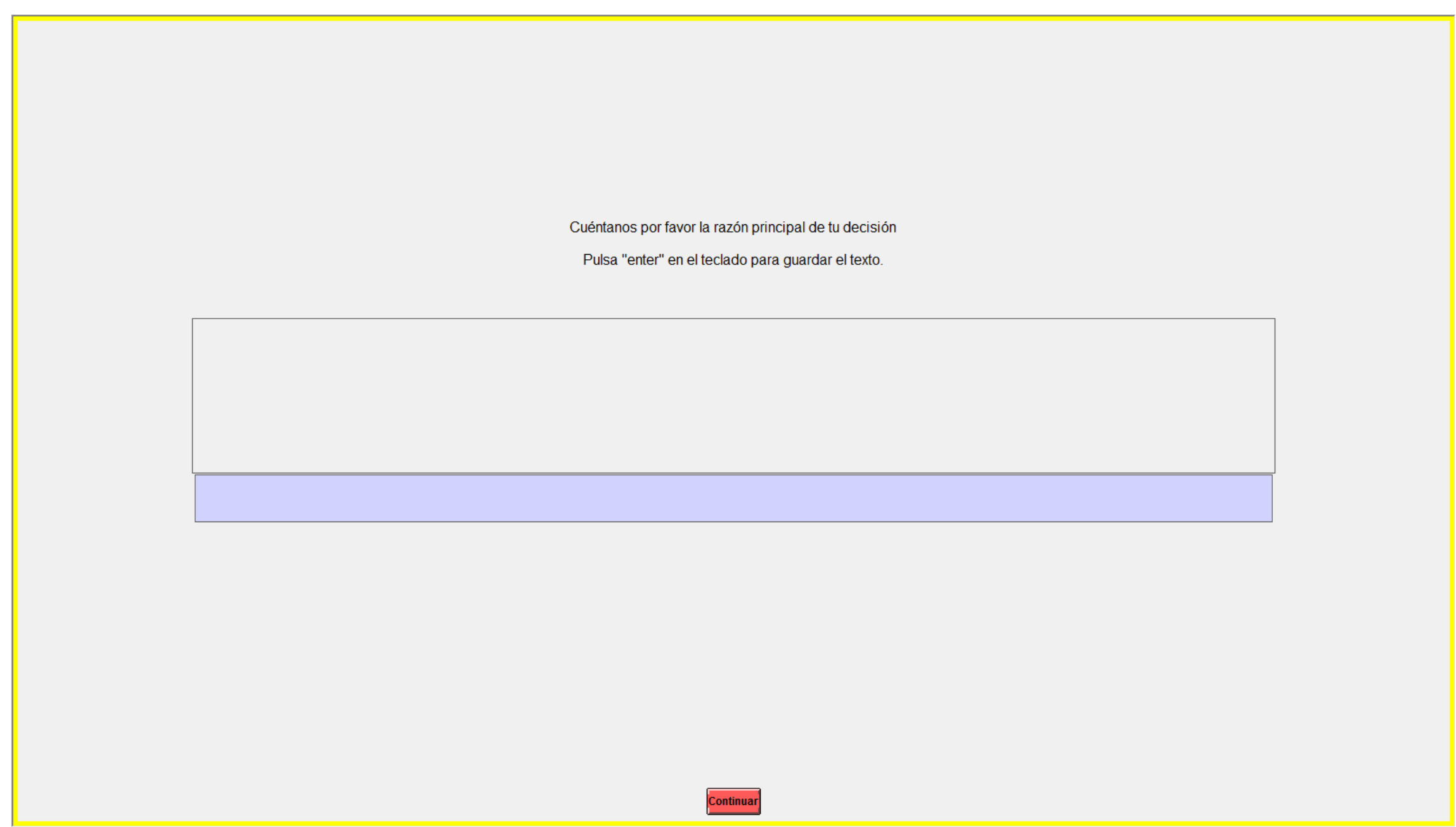


Framed PG. Screen 3A: Closed-format explanation from a Contributor

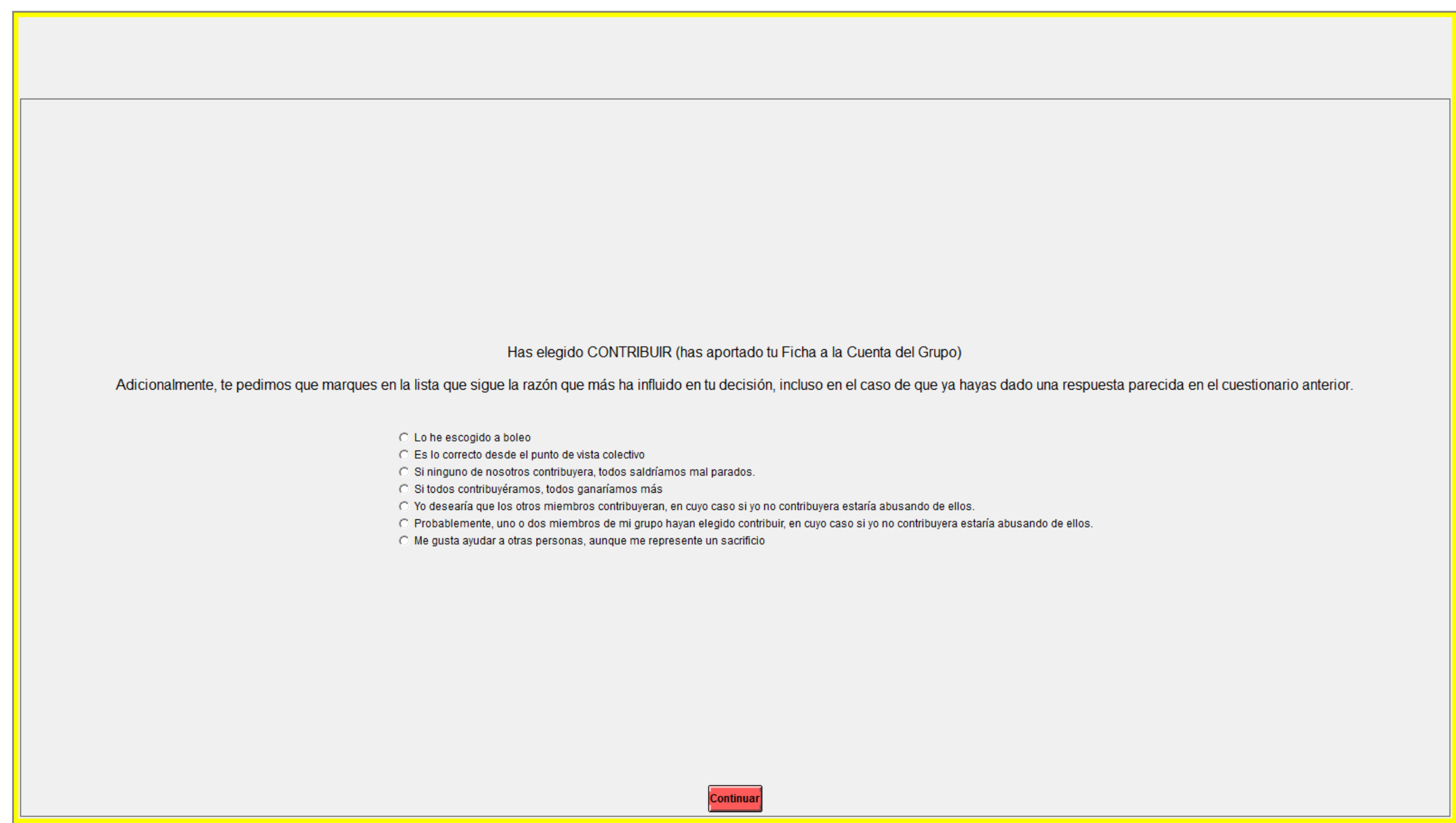


Framed PG. Screen 3B: Closed-format explanation from a Non Contributor

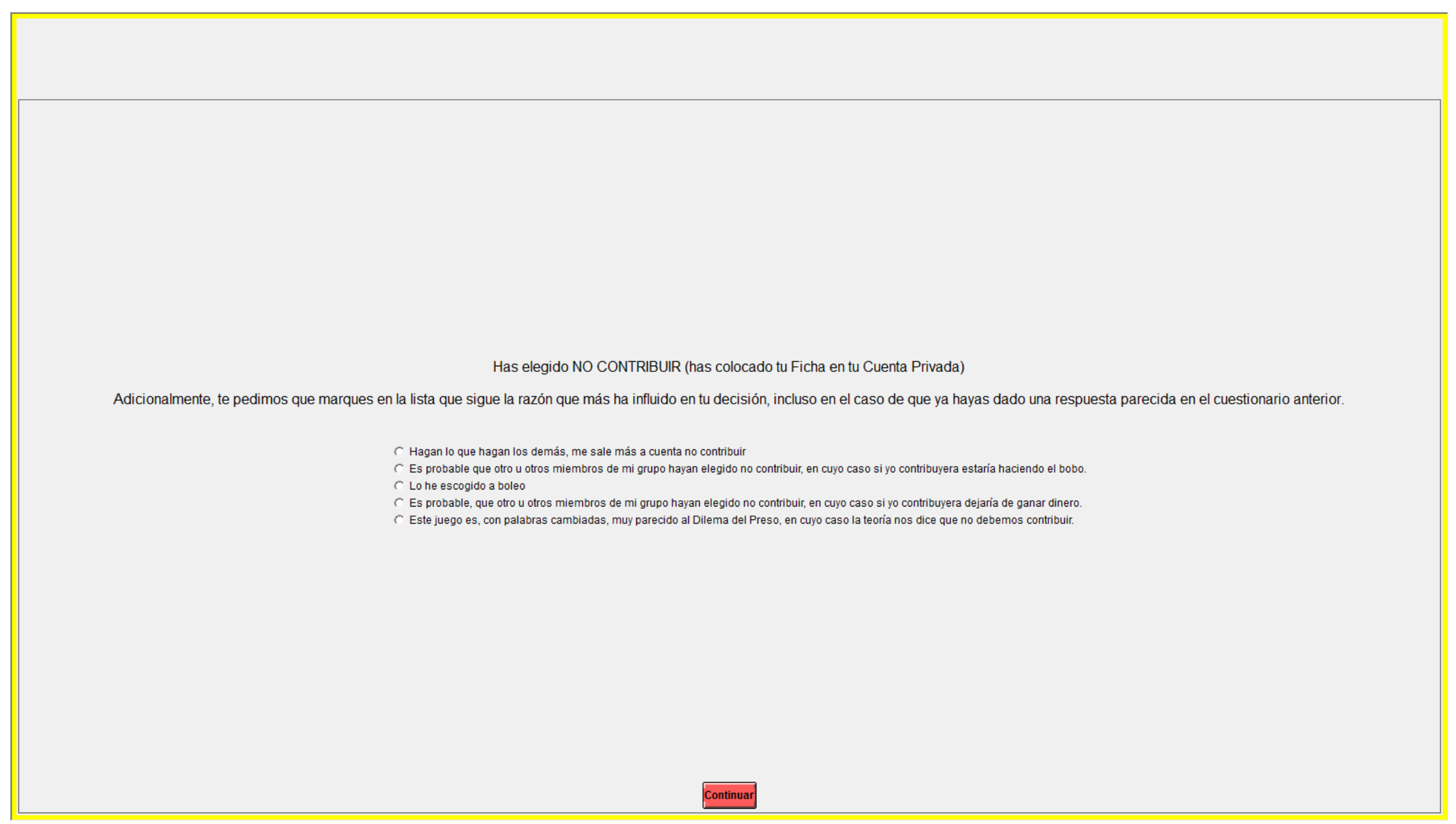


Framed PG. Screen 4: Earnings statement (example)

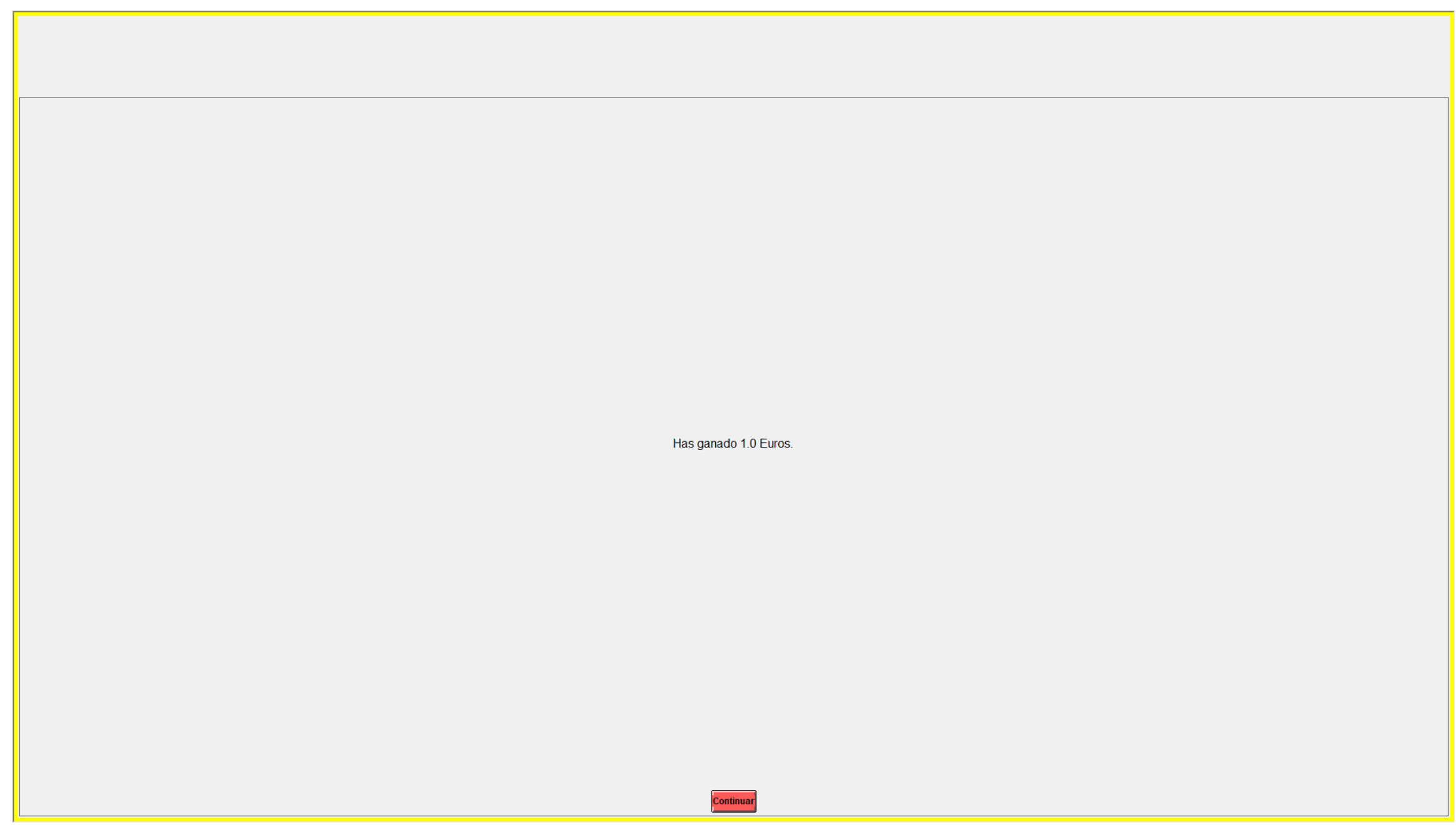


A.4. 2-Person, Frameless Prisoner's Dilemma (PD) Treatment

PD. Screen 1: Instructions and choice

Vas a jugar junto con otro jugador que ha sido escogido al azar entre los participantes en este experimento. Puedes

escoger o bien CíRCULO o bien CUADRADO, pero no ambos. El otro jugador puede, igualmente, escoger CIRCULO o

decisión, y para ambos se calculan de la misma manera. Más exactamente, tus ganancias vienen descritas en el cuadro

siguiente y, como verás, las ganancias del otro jugador se calculan exactamente de la misma manera.

\begin{tabular}{|c|c|c|}
\hline & Tu cuadro de ganancias & El otrojugador escoge cuADRADO \\
\hline Tú escoges circulo & El otrojugador escoge circulo & Tú ganas $1 €$ \\
\hline Tú escoges CUADRADo & Tú ganas 10€ & Tú ganas $6 €$ \\
\hline
\end{tabular}

Las ganancias del otro jugador

\begin{tabular}{|c|c|c|}
\hline & Tú escoges círculo & Tú escoges CUADRADO \\
\hline El otro jugador escoge círCULL & El otro jugador gana $10 €$ & El otro jugador gana $1 €$ \\
\hline El otro jugador escoge CUADRADO & El otro jugador gana $15 €$ & El otro jugador gana $6 €$ \\
\hline
\end{tabular}

Tú escoges: 
PD. Screen 2: Open-format explanation

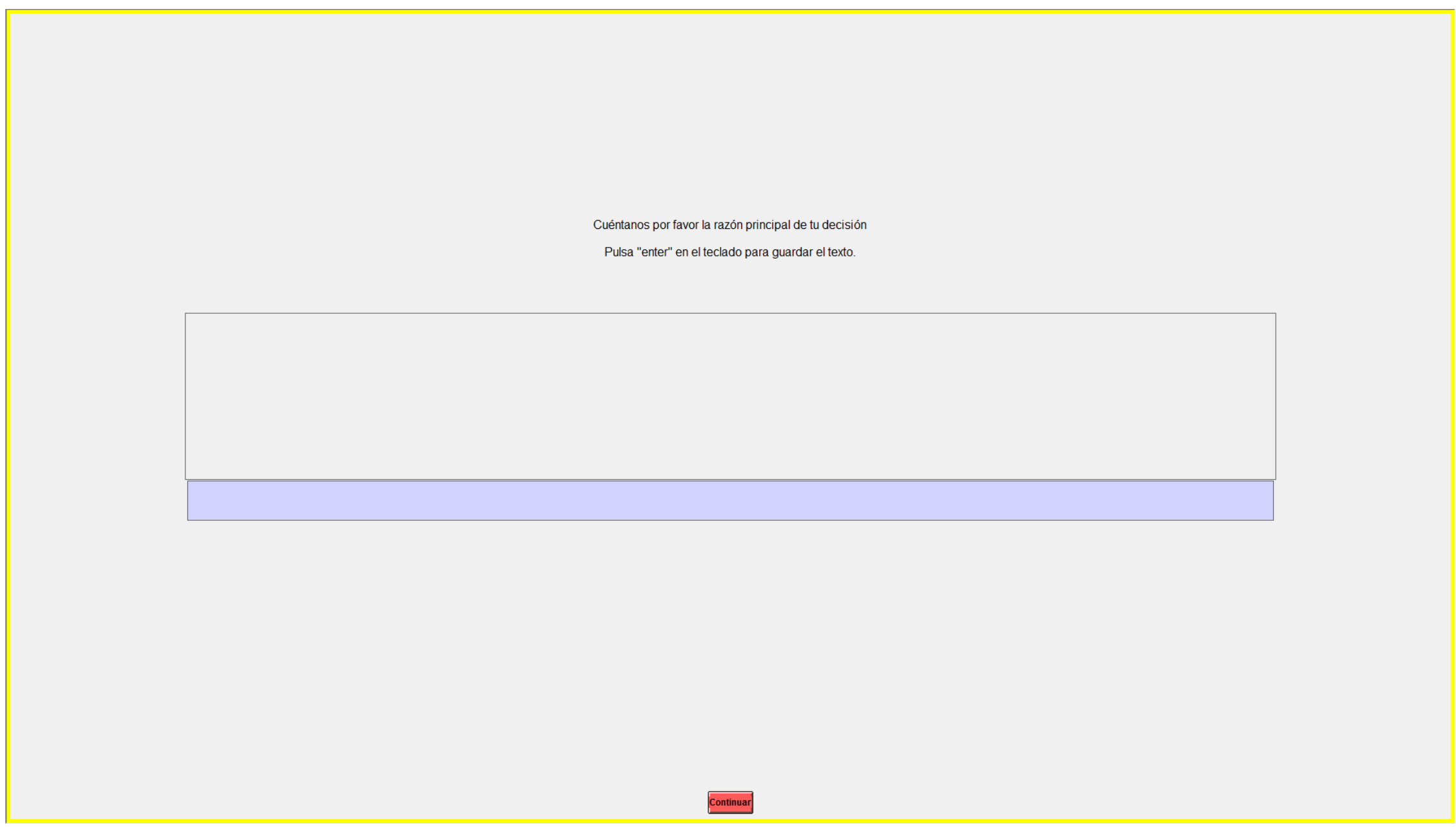


PD. Screen 3A: Closed-format explanation from a participant who chose CIRCLE

Has elegido circulo.

Adicionalmente, te pedimos que marques en la lista que sigue la razón que más ha influido en tu decisión, incluso en el caso de que ya hayas dado una respuesta parecida en el cuestionario anterior.

$\checkmark$ Lohe escogido a boleo

Es lo correcto desde el punto de vista colectivo

Silos dos jugáamos CUADRADO, los dos saltriamos mal parados

Sil los dos jugáramos circulo, en conjunto ganariamos más

Yo desearia que Il ottra persona eligierar circCULO, en ayyo caso s siyo eligiera CUADRADO estaria abusando de ella

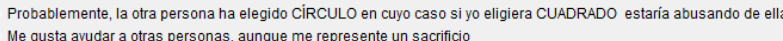


PD. Screen 3B: Closed-format explanation from a participant who chose SQUARE

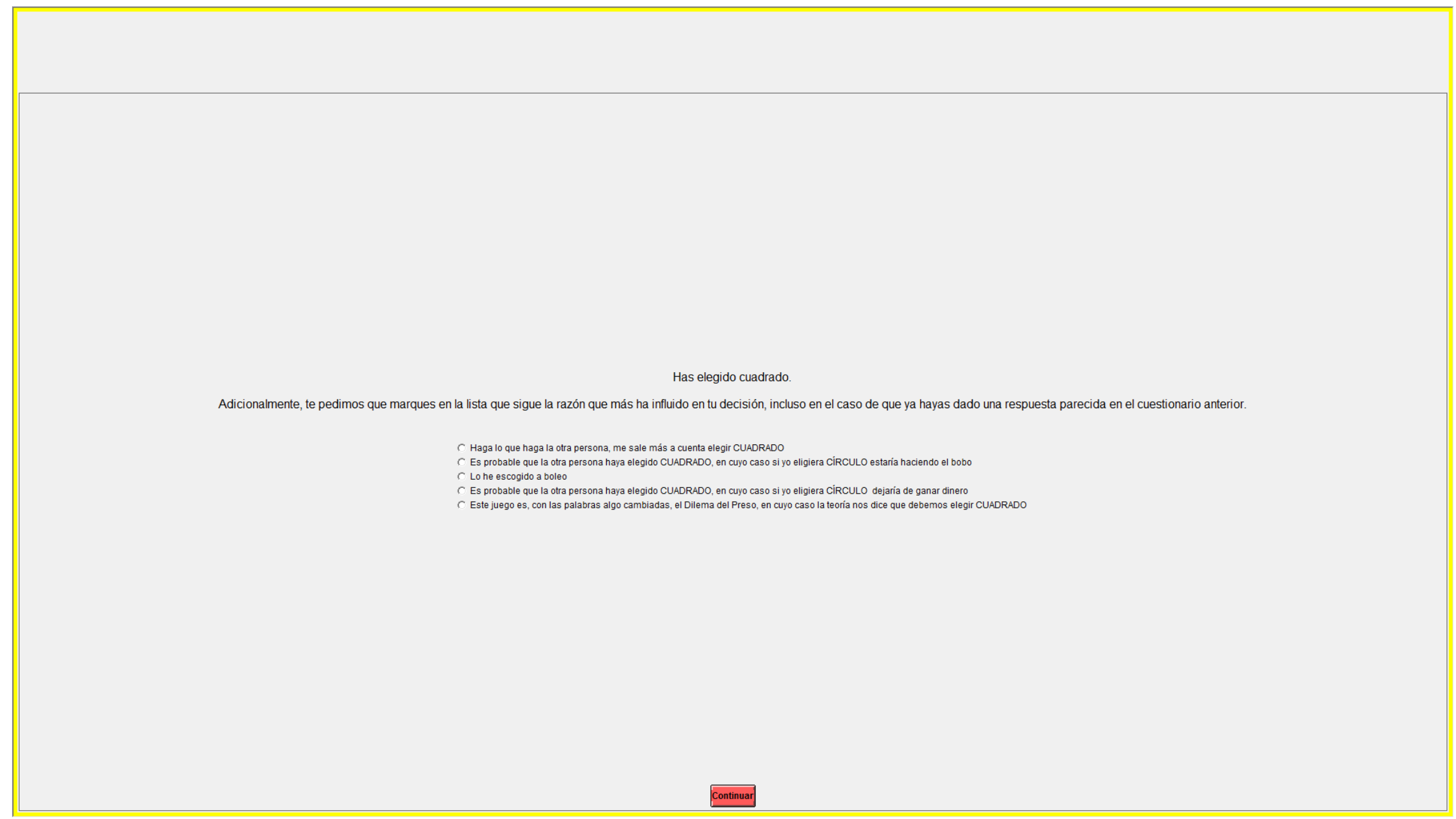


PD. Screen 4: Earnings statement (example)

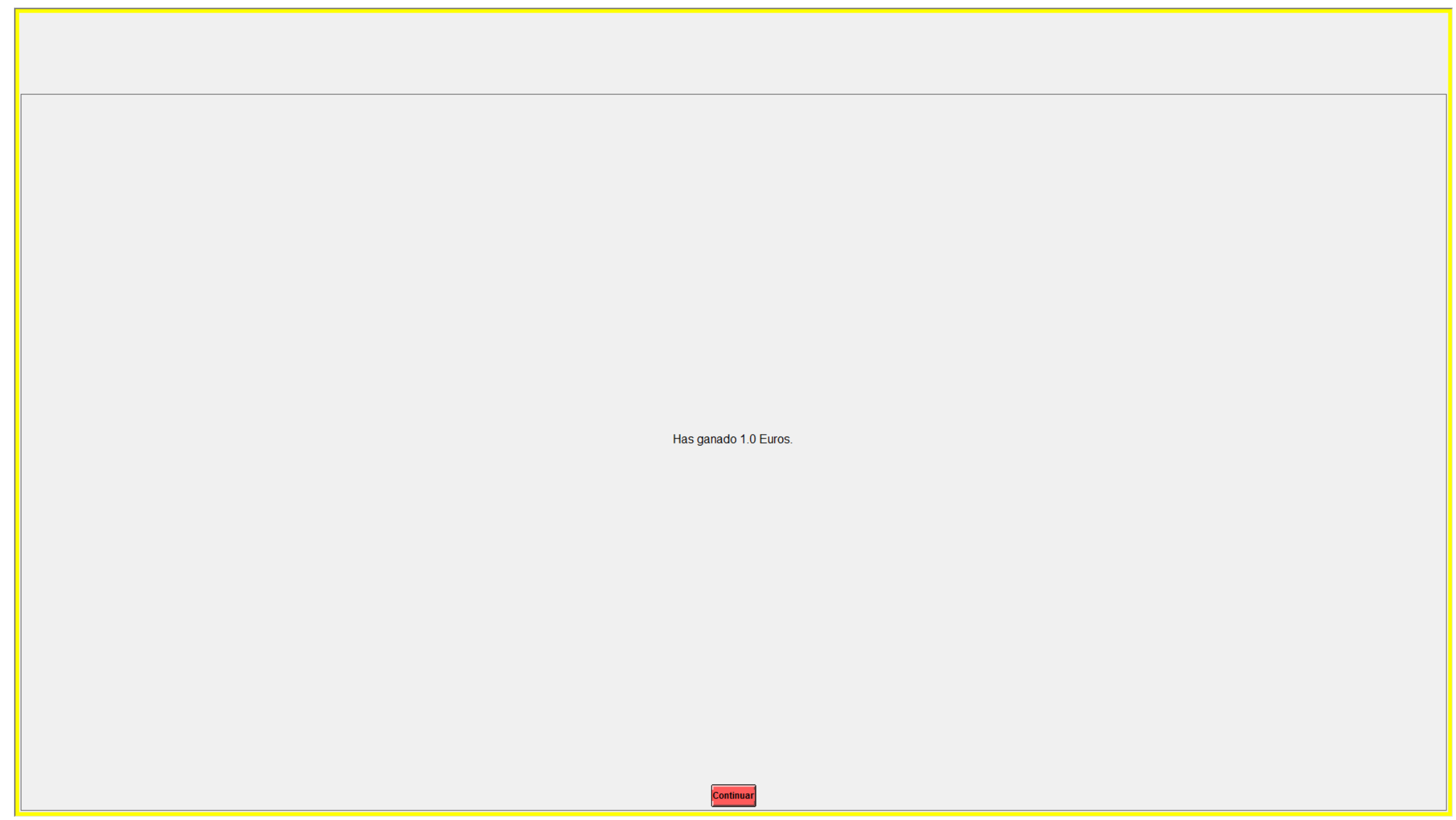


A.5. 2-Person, Riskless and Frameless Prisoner's Dilemma (PD)

Riskless. Screen 1: First screen of instructions

En este experimento, tus ganancias van a depender de tus decisiones, decisiones que

permanecerán anónimas, es decir, nadie sabrá qué decisiones has tomado. Para mantener este anonimato:

1- Antes de iniciar el experimento, deberás firmar el documento que se encuentra sobre tu mesa,

donde acreditas que estás participando en este experimento remunerado. Observa que la cantidad

que vas a ganar no aparece en el documento, ya que esta cantidad depende de tus decisiones, que queremos no sean identificadas individualmente.

2- Al final del experimento aparecerá una pantalla con la cifra de las ganancias que has obtenido con tus decisiones y, a continuación, una pantalla con una letra. Luego, un administrativo pasará por tu mesa y, a la vista de la letra en tu pantalla, te dará un sobre cerrado con tus ganancias. Para mantener tu anonimato, en esta pantalla no constará ni tu nombre ni el número de tu terminal. Podrás entonces salir de la sala y abrir el sobre. 
Riskless. Screen 2: Second screen of instructions

Vas a jugar con otro jugador que ha sido escogido al azar entre los participantes en este

experimento. En principio tanto tú como el otro jugador deberéis elegir entre dos opciones: CíRCULO

y CUADRADO. Tanto tus ganancias como las del jugador con quien estás emparejado/a dependen de

tu decisión y de su decisión, y para ambos se calculan de la misma manera. Más exactamente, tus

ganancias vienen descritas a continuación en la primera tabla, y, como verás, las ganancias del otro

jugador, que vienen descritas en la segunda tabla, se calculan exactamente de la misma manera.

\section{Tu tabla de ganancias}

\begin{tabular}{|c|c|c|}
\hline & El otro jugador escoge cirRcuLo & El otro jugador escoge CUADRADO \\
\hline Tú escoges cíRCuLO & Tú ganas 10€ & Tú ganas $1 €$ \\
\hline Tú escoges CUADRADO & Tú ganas 15€ & Tú ganas $6 €$ \\
\hline
\end{tabular}

La tabla de ganancias del otro jugador

\begin{tabular}{|c|c|c|}
\hline & Tú escoges cirCuLo & Tú escoges CUADRADO \\
\hline El otro jugador escoge CiRCuLo & El otro jugador gana 10€ & El otro jugador gana 1€ \\
\hline El otro jugador escoge CUADRADO & El otro jugador gana 15€ & El otro jugador gana $6 €$ \\
\hline
\end{tabular}

Ten en cuenta que no podrás volver a las pantallas anteriores. Pero no tienes necesidad de memorizar las tablas: volverán a aparecer cuando sea necesario. 
Riskless. Screen 3: Third screen of instructions

El ordenador designará al azar, con $50 \%$ de probabilidad, a uno de vosotros dos

como jugador pasivo y al otro como jugador activo. El jugador pasivo deberá

forzosamente elegir CÍRCULO mientras que el jugador activo será libre de elegir de

forma anónima CÍRCULO o CUADRADO.

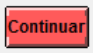




\section{Note.}

The following screens appear in the stated order to a participant who has been randomly assigned as active in the first part and passive in the second part.

A participant who, on the contrary, has been designated passive in the first part and active in the second part has screen 8 exchanged for screens $4,5,6 \mathrm{~A}$ or $6 \mathrm{~B}$

(i. e, the screens appear to him/her in the order 1, 2, 3, 8, 1, 4, 5, 6A or 6B, 9, 10)

with the text of screens 4 and 8 slightly modified, so that 8 starts "Has sido designado jugador activo," and 4 starts "El experimento se repite, con la diferencia que ahora tú eres jugador pasivo." 
Riskless. Screen 4: Choice for active player

Has sido designado jugador activo. Dado que el jugador con el que estás emparejado es pasivo, y por tanto está obligado a escoger CIRCULO, tu tabla de ganancias y la del otro jugador se simplifica de la forma siguiente:

Tu tabla simplificada de ganancias:

\begin{tabular}{|c|c|}
\hline & El otro jugador escoge cíRcuLo \\
\hline Tú escoges círCuLo & Tú ganas 10€ \\
\hline Tú escoges CUADRADO & Tú ganas 15€ \\
\hline
\end{tabular}

La tabla simplificada de ganancias del otro jugador:

\begin{tabular}{|l|c|c|}
\hline & Tú escoges circuLo & Tú escoges CUADRADO \\
\hline El otro jugador escoge CiRCULO & El otro jugador gana 10€ & El otro jugador gana $1 €$ \\
\hline
\end{tabular}

En otras palabras:

* Si pulsas CiRCULO, tú ganas $10 €$ y el otro jugador gana $10 €$.

* Si pulsas CUADRADO, tú ganas $15 €$ y el otro jugador gana $1 €$.

Por favor, pulsa el botón de tu elección. Ten en cuenta que no puedes cambiar tu elección una vez efectuada.

Tú escoges:

CírCULO 
Riskless. Screen 5: Open-format explanation from active player

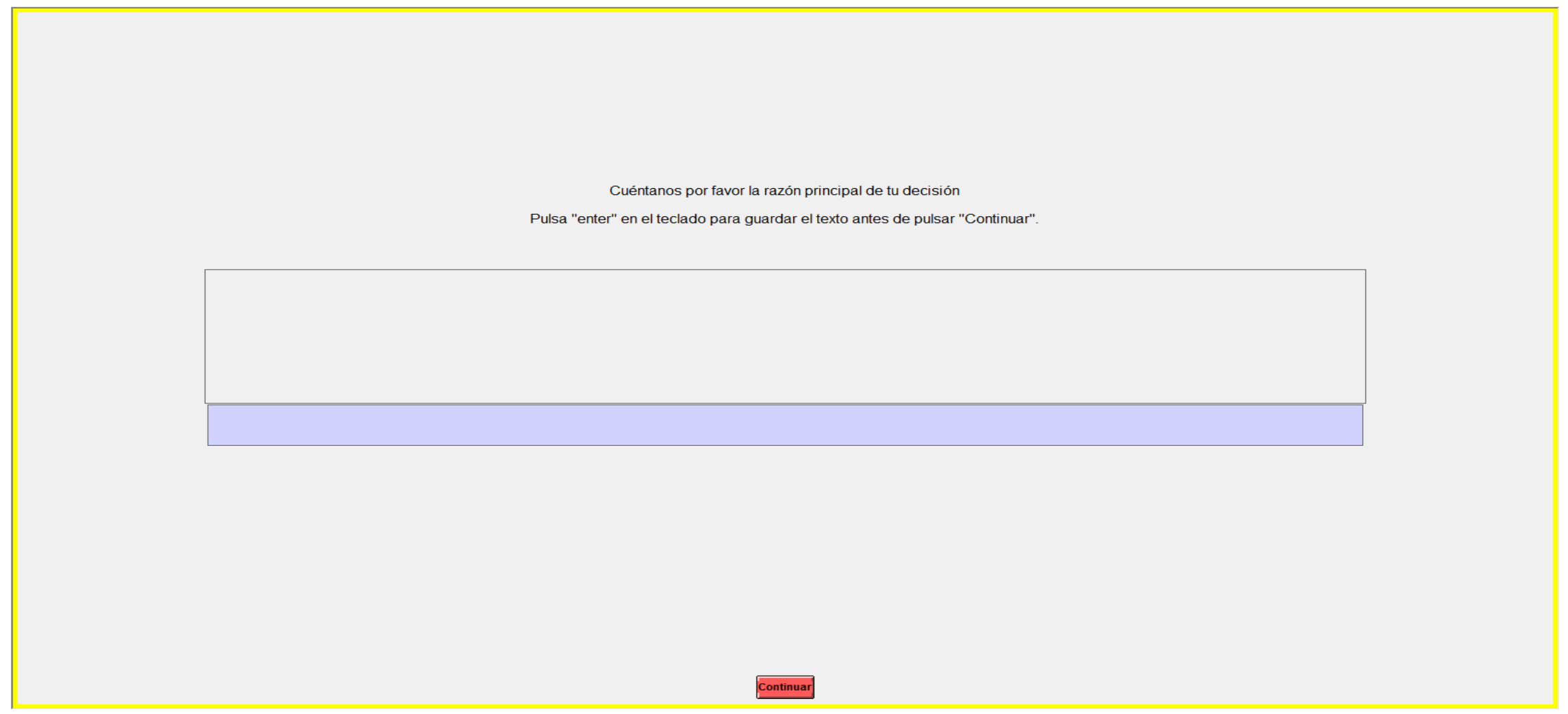


Riskless. Screen 6A: Closed-format explanation from active player who chose CIRCLE

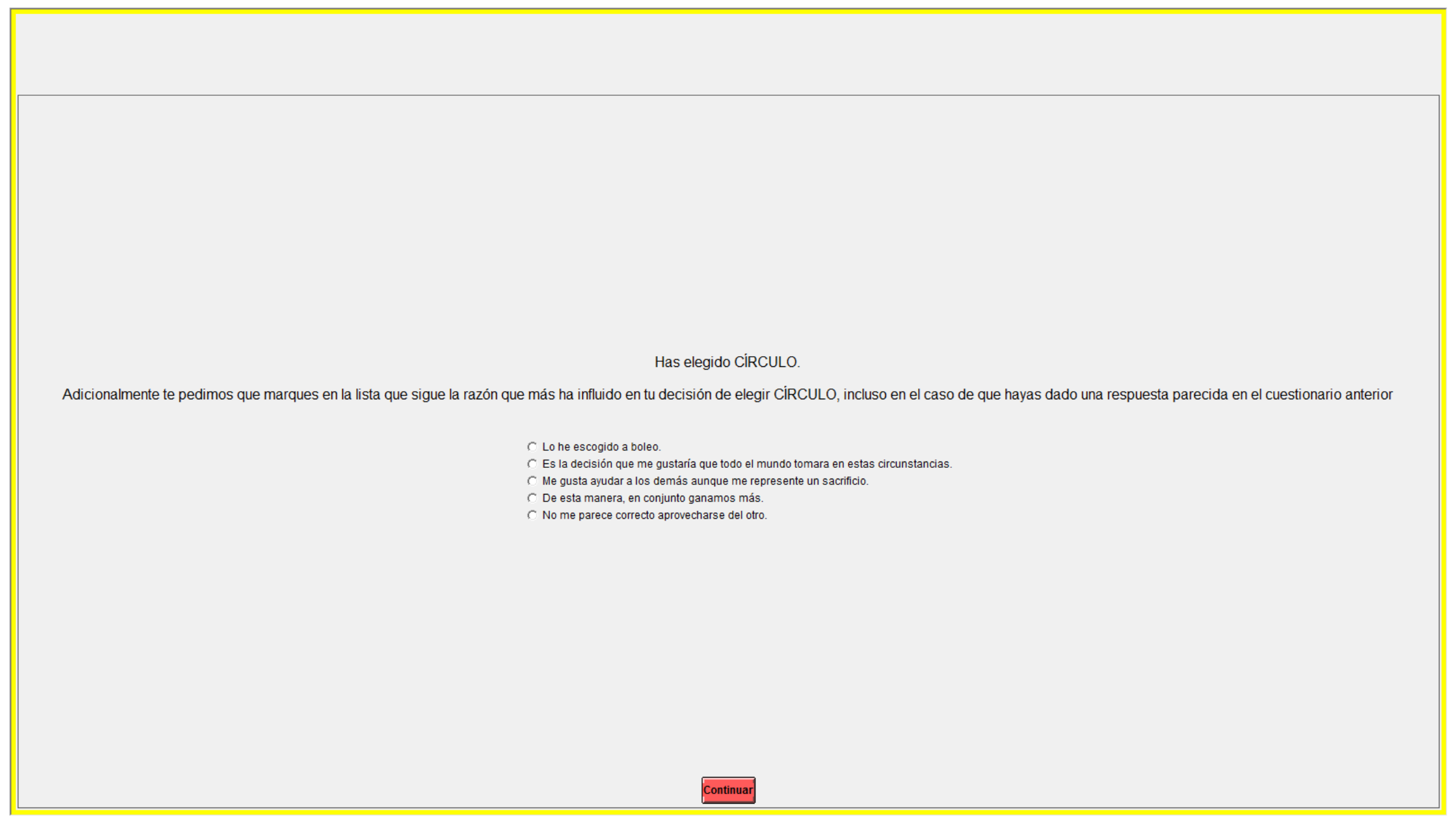


Riskless. Screen 6B: Closed-format explanation for active player who chose SQUARE

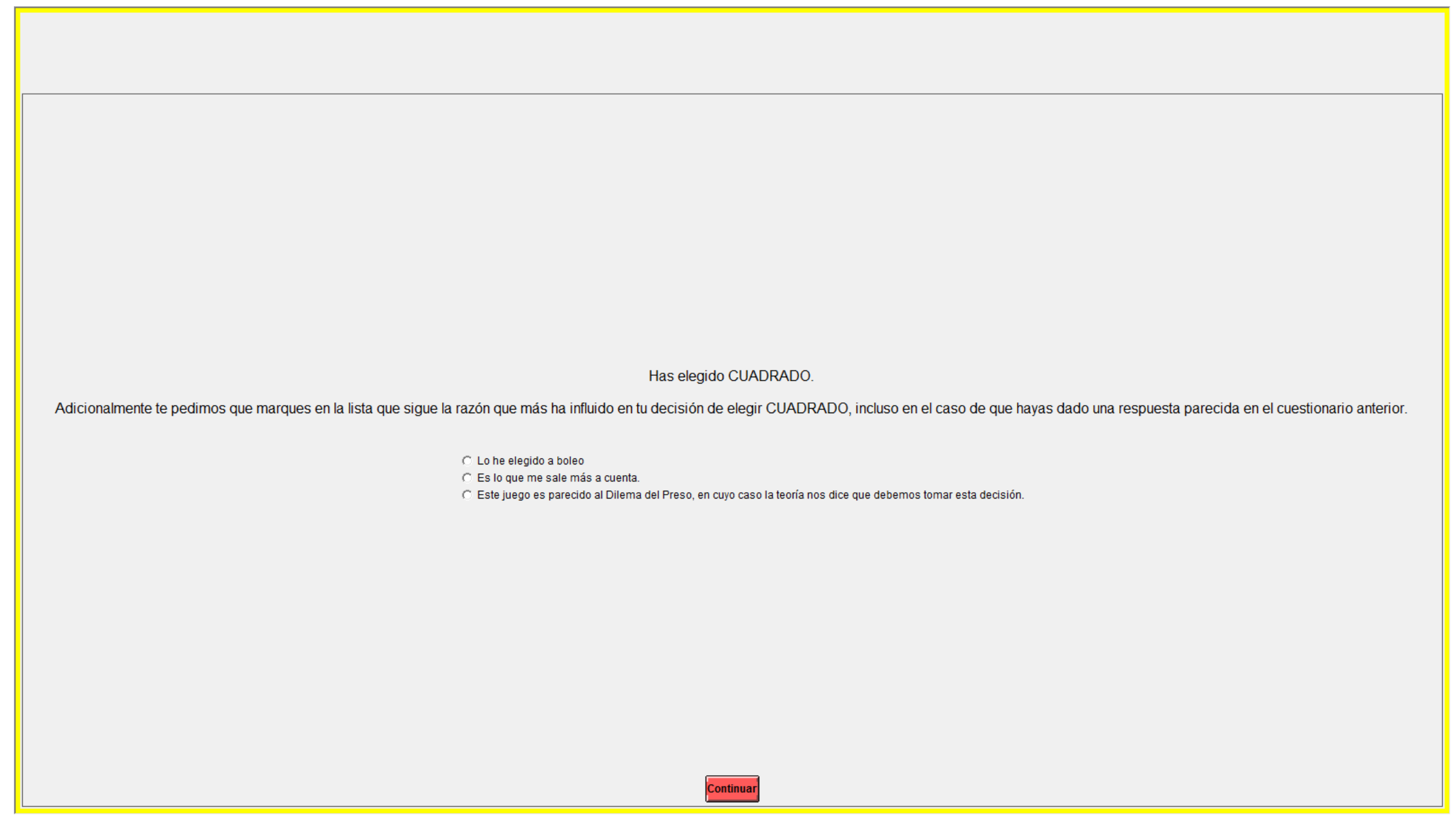


Riskless. Screen 7: Continuation

EL EXPERIMENTO CONTINUA ... 
Riskless. Screen 8: Now you are passive

El experimento se repite, con la diferencia que ahora tú eres el jugador pasivo. De nuevo se te va a emparejar al azar con otro jugador. El jugador con el que vas a estar emparejado es activo, y por tanto, va a ser libre de escoger CIRCULO o CUADRADO, de forma que tu tabla de ganancias y la del otro jugador se simplifica de la forma siguiente:

Tu tabla simplificada de ganancias

\begin{tabular}{|l|c|c|}
\hline & El otro jugador escoge CiRCULO & El otro jugador escoge CUADRADO \\
\hline Tú escoges cíRCuLo & Tú ganas $10 €$ & Tú ganas $1 €$ \\
\hline
\end{tabular}

La tabla simplificada de ganancias del otro jugador:

\begin{tabular}{|c|c|}
\hline & Tú escoges CíRCULO \\
\hline El otro jugador escoge CIRCULO & El otro jugador gana 10€ \\
\hline El otro jugador escoge CUADRADO & El otro jugador gana 15€ \\
\hline
\end{tabular}

En otras palabras:

* Si el otro jugador escoge CIRCULO, tú ganas $10 €$ y el otro jugador gana $10 €$.

* Si el otro jugador escoge CUADRADO, tú ganas $1 €$ y el otro jugador gana $15 €$.

Como jugador pasivo, debes escoger forzosamente CIRCULO. Pulsa el botón. 
Riskless. Screen 9: Earnings statement (example)

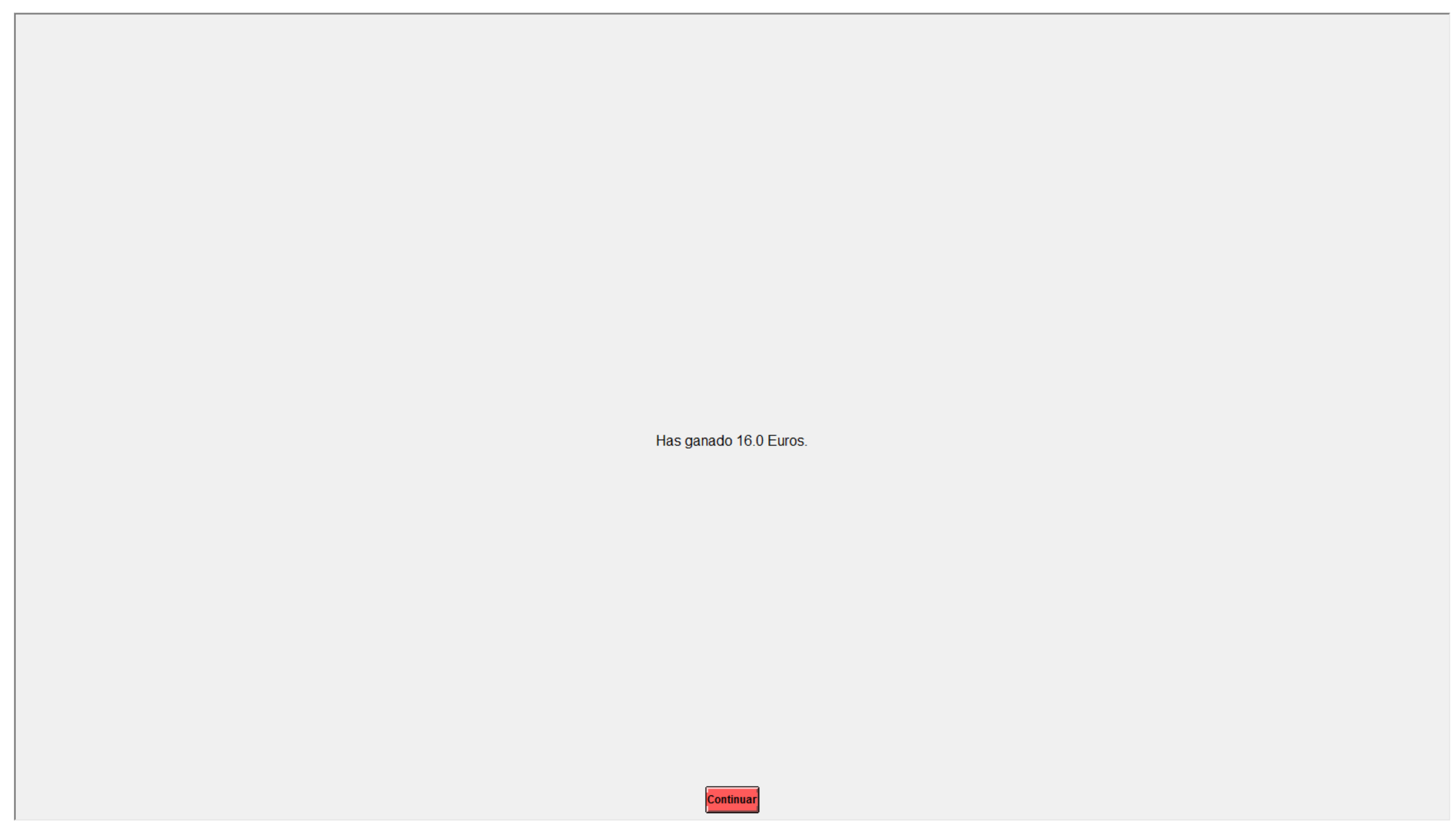


Riskless. Screen 10: Payment letter code (example)

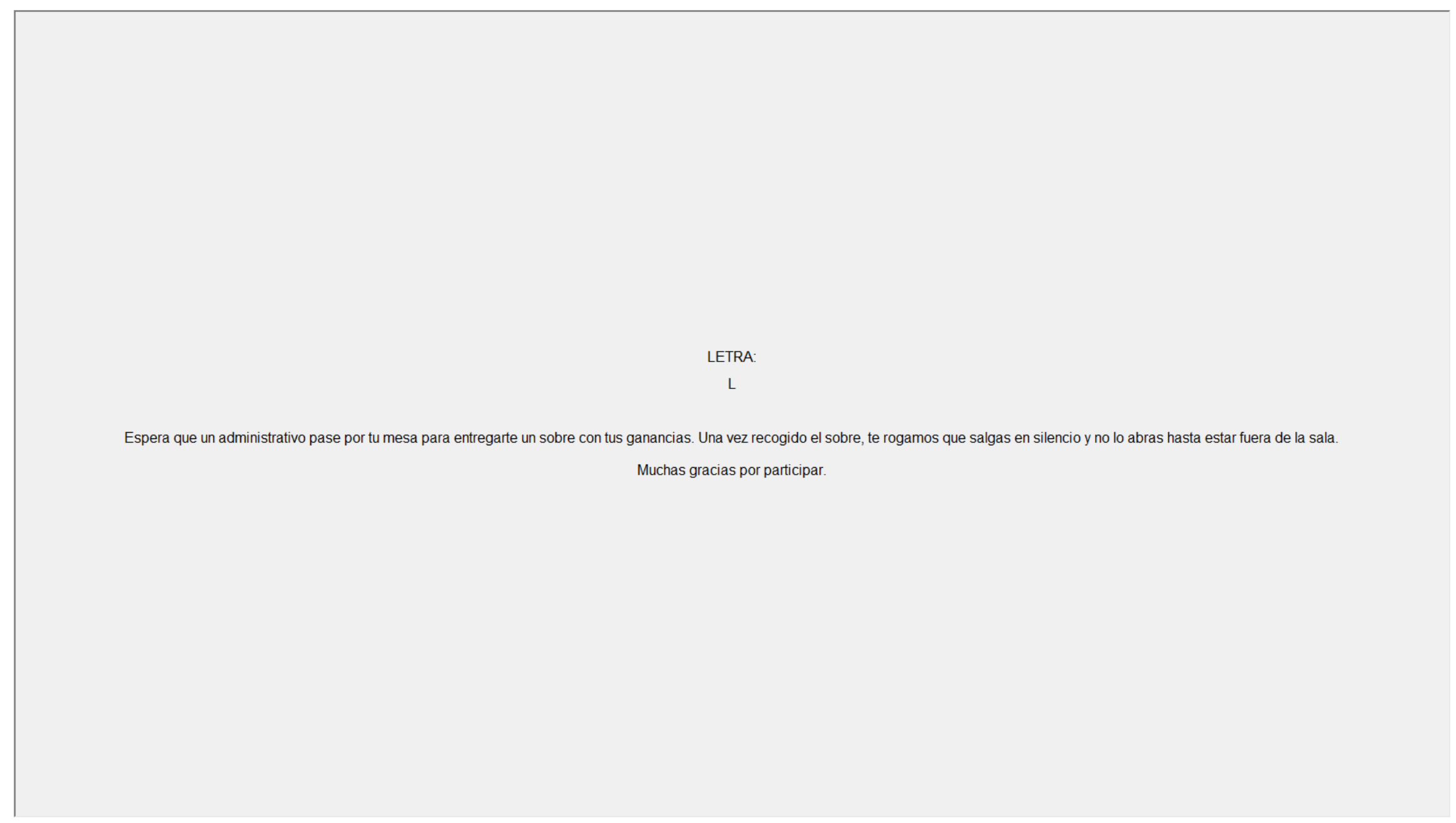




\section{REFERENCES}

Barcelo, Hélène, and Valerio Capraro (2015). "Group size effect on cooperation in one-shot social dilemmas,” Scientific Reports 5:7937 | DOI: 10.1038/srep07937

Bonacich, Phillip, Gerald H. Shure, James P. Kahan and Robert J. Meeker (1976). "Cooperation and group size in the N-person Prisoners' Dilemma," Journal of Conflict Resolution 20(4), 687-706.

Bowles, Samuel, and Herbert Gintis (2011). A Cooperative Species: Human Reciprocity and its Evolution. Princeton: Princeton University Press.

Clark, Kenneth, and Martin Sefton (2001). "The Sequential Prisoner's Dilemma: Evidence on reciprocation," The Economic Journal 111(468), 51-68

Colman, Andrew M. (1995). Game Theory and its Applications in the Social and Biological Sciences, Second Edition. Oxford: Butterworth-Heinemann.

Cookson, R. (2000). "Framing effects in public goods experiments," Experimental Economics 3, 55-79.

Fischbacher, Urs, Simon Gächter and Ernst Fehr (2001). "Are people conditionally cooperative? Evidence from a public goods experiment," Economics Letters 71, 397-404.

Isaac, Marc, James Walker and Arlington Williams (1994). "Group size and the voluntary provision of public goods," Journal of Public Economics 54, 1-36.

Ledyard, John (1995). "Public goods: A survey of experimental research," Chapter 2 in Alvin Roth and John Kagel, Editors, Handbook of Experimental Economics. Princeton: Princeton University Press.

Nosenzo, Daniele, Simone Quercia and Martin Sefton (2015). "Cooperation in small groups: The effect of group size," Experimental Economics 18, 4-14.

Roemer, John E. (2015a). "Kantian optimization: A microfoundation for cooperation," Journal of Public Economics 127, 45-57.

Roemer, John E. (2015b). "How we (do and could) cooperate...perhaps," Unpublished, September.

Weimann, Joachim, Jannette Brosig-Koch, Heike Hennig-Schmidt, Claudia Keser, and Christian Stahr (2012). "Public good experiments with large groups." Available at https://ideas.repec.org/p/mag/wpaper/120009.html (2012). 